\title{
Precipitation and Crystallization Used in the Production of Metal Salts for Li-Ion Battery Materials: A Review
}

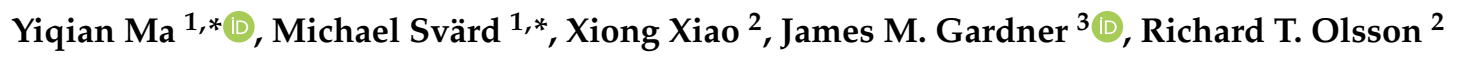 \\ and Kerstin Forsberg ${ }^{1, *}$ \\ 1 Department of Chemical Engineering, KTH Royal Institute of Technology, Teknikringen 42, \\ 11428 Stockholm, Sweden \\ 2 Department of Fiber and Polymer Technology, KTH Royal Institute of Technology, Teknikringen 56, \\ 11428 Stockholm, Sweden; xiongxi@kth.se (X.X.); rols@kth.se (R.T.O.) \\ 3 Department of Chemistry, KTH Royal Institute of Technology, Teknikringen 30, 11428 Stockholm, Sweden; \\ jgardner@kth.se \\ * Correspondence: yiqianm@kth.se (Y.M.); micsva@kth.se (M.S.); kerstino@kth.se (K.F.); \\ Tel.: +46-87906404 (Y.M.)
}

Received: 18 October 2020; Accepted: 27 November 2020; Published: 30 November 2020

check for updates

\begin{abstract}
Li-ion battery materials have been widely studied over the past decades. The metal salts that serve as starting materials for cathode and production, including $\mathrm{Li}_{2} \mathrm{CO}_{3}, \mathrm{NiSO}_{4}, \mathrm{CoSO}_{4}$ and $\mathrm{MnSO}_{4}$, are mainly produced using hydrometallurgical processes. In hydrometallurgy, aqueous precipitation and crystallization are important unit operations. Precipitation is mainly used in the processes of impurity removal, separation and preliminary production, while controlled crystallization can be very important to produce a pure product that separates well from the liquid solution. Precipitation and crystallization are often considered in the development of sustainable technologies, and there is still room for applying novel techniques. This review focuses on precipitation and crystallization applied to the production of metal salts for Li-ion battery materials. A number of novel and promising precipitation and crystallization methods, including eutectic freeze crystallization, antisolvent crystallization, and homogeneous precipitation are discussed. Finally, the application of precipitation and crystallization techniques in hydrometallurgical recycling processes for Li-ion batteries are reviewed.
\end{abstract}

Keywords: precipitation; crystallization; metal salts; Li-ion batteries; recycling; hydrometallurgy

\section{Introduction}

Aqueous precipitation and crystallization refer to unit operations that generate a solid from a supersaturated solution [1], wherein supersaturation generates a chemical potential that drives the reaction. The non-equilibrium, supersaturated condition can be induced in a variety of ways, including removal of solvent by evaporation, addition of another solvent, change of temperature or pressure, addition of other solutes, oxidation-reduction reactions, or combinations of these [2]. In hydrometallurgy, precipitation is mainly used as a process for impurity removal, separation and preliminary production, while crystallization is often used to produce a pure product and one that separates well from the solution [3]. The development of precipitation and crystallization technologies with high selectivity and low energy consumption is one of the challenges in hydrometallurgy.

Recently, Li-ion battery materials, especially the cathode materials, have become a research hotspot. Metal salts of $\mathrm{Li}, \mathrm{Ni}, \mathrm{Co}$ and $\mathrm{Mn}$ are the most important raw materials for the cathode materials $[4,5]$. The production of metal salts for Li-ion battery materials usually involves a partial 
or complete hydrometallurgical process, including precipitation and crystallization processes [6-9]. This review focuses on the processes and advances of precipitation and crystallization as used in the production of these metal salts for use in the manufacturing of Li-ion battery materials.

\subsection{Methods and Applications of Aqueous Precipitation and Crystallization}

The terminology of precipitation and crystallization processes is often unclear, with the terms often used loosely. The distinction between the terms precipitation and crystallization is generally based on the rate of the process and on the form of the solid particles produced. Crystallization is the formation of solids with a crystalline structure from a liquid phase. Precipitation as used within the current context is the formation of solids (not necessarily crystalline, could also be amorphous) from a liquid phase, under conditions of very high supersaturation. The term precipitation often tends to be applied to processes involving chemical reactions between added reagents and/or other species in the solution, where the products have very low solubility. However, the terminology sometimes overlap. For example, the production of $\mathrm{Li}_{2} \mathrm{CO}_{3}$ by the reaction of $\mathrm{Na}_{2} \mathrm{CO}_{3}$ and $\mathrm{Li}_{2} \mathrm{SO}_{4}$ in solution is usually called crystallization [10], but the production of rare earth carbonates in a similar manner is usually referred to as precipitation [11]. Table 1 shows the terminology of precipitation and crystallization based on the driving force of supersaturation and the form of the product.

Table 1. The terminology of precipitation and crystallization under different conditions.

\begin{tabular}{|c|c|c|}
\hline $\begin{array}{l}\text { Method for Generation of } \\
\text { Supersaturation }\end{array}$ & $\begin{array}{l}\text { Amorphous Product } \\
\text { (Precipitation) }\end{array}$ & $\begin{array}{l}\text { Crystalline Product (Precipitation and/or } \\
\text { Reaction Crystallization) }\end{array}$ \\
\hline Chemical reaction & $\begin{array}{l}\text { e.g., iron precipitation by } \\
\mathrm{Fe}(\mathrm{OH})_{3} \text { or } \mathrm{Fe}(\mathrm{OH})_{2}\end{array}$ & $\begin{array}{l}\text { e.g., iron removal by jarosite or goethite } \\
\text { precipitation [12], chemical precipitation to } \\
\text { produce ultrafine } \mathrm{BaSO}_{4}[13], \mathrm{Li}_{2} \mathrm{CO}_{3} \\
\text { crystallization by the reaction of } \mathrm{Li}^{+} \text {and } \mathrm{CO}_{3}{ }^{2-} \\
\text { [10], rare earth carbonates precipitation by the } \\
\text { reaction of rare earth ions and } \mathrm{CO}_{3}{ }^{2-}[11], \\
\text { Silicate removal by kaolinite precipitation [14], } \\
\text { Hydrothermal synthesis of } \mathrm{LiCoO}_{2} \text { [15]. }\end{array}$ \\
\hline Physical change & $\begin{array}{l}\text { e.g., precipitation of the } \\
\text { colloidal particles in } \\
\text { wastewater by } \\
\text { adding flocculant. }\end{array}$ & $\begin{array}{l}\text { e.g., evaporative crystallization to produce } \\
\left(\mathrm{NH}_{4}\right)_{10}\left(\mathrm{H}_{2} \mathrm{~W}_{12} \mathrm{O}_{42}\right) \cdot 4 \mathrm{H}_{2} \mathrm{O}(\mathrm{APT}) \text { [8], } \\
\text { eutectic freeze crystallization to produce } \\
\mathrm{CuSO}_{4} \cdot 5 \mathrm{H}_{2} \mathrm{O}[16] \text {, antisolvent precipitation of } \\
\mathrm{REE} \text { sulfate hydrates [17], antisolvent } \\
\text { crystallization of }\left(\mathrm{NH}_{4}\right)_{3} \mathrm{ScF}_{6} \text { [18]. Aluminum } \\
\text { removal by } \mathrm{KAl}\left(\mathrm{SO}_{4}\right)_{2} \cdot 12 \mathrm{H}_{2} \mathrm{O} \text { crystallization [19]. }\end{array}$ \\
\hline
\end{tabular}

Precipitation and crystallization processes both obey the same basic rules: supersaturation is generated, which is the driving force and the necessary prerequisite for nucleation and growth. Thermodynamically, the condition for when a solid phase forms in the solution at constant temperature and pressure can be written $[2,20]$ :

$$
\Delta \mu=-\mathrm{RT} \cdot \ln \left(a / a_{0}\right)<0
$$

where $\Delta \mu=$ the difference in solute chemical potential, corresponding to the change in molar Gibbs energy for the transformation, $\mathrm{R}=$ the ideal gas constant, $T=$ the absolute temperature, $a=$ the activity of the solute in the solution, and $a_{0}=$ the activity of the solute at equilibrium with the solid phase. The supersaturation ratio, $S$, is defined as the ratio $a / a_{0}$. Provided activities can be approximated by concentrations (i.e., the concentration-dependence of activity coefficients can be neglected), the supersaturation ratio can be expressed as:

$$
S=a / a_{0} \approx C / C_{e q}
$$


where $C=$ the solute concentration and $C_{e q}=$ the solubility.

The solution is supersaturated when $S>1$. Retaining the above-mentioned approximation of the activity ratio, the relative supersaturation may be defined as:

$$
\left(C-C_{e q}\right) / C_{e q}=S-1
$$

Considering a common precipitation or crystallization reaction, the supersaturation ratio can be expressed in terms of the concentrations of reactants and the solubility product, $K_{s p}$ :

$$
\begin{gathered}
A(a q)+B(a q) \rightarrow A B(s) \\
S=\frac{[A][B]}{K_{s p}} \\
K_{s p}=[A]_{e q}[B]_{e q}=\exp \left(-\Delta G^{0} / R T\right)
\end{gathered}
$$

In hydrometallurgical processes, precipitation by chemical reaction is common. Table 2 lists the main reaction-based methods. Precipitation by chemical reaction may yield both amorphous and crystalline products, e.g., precipitation of iron can form into crystalline spinel ferrite $\left(\mathrm{Fe}_{3} \mathrm{O}_{4}\right)$, or amorphous iron hydroxides.

Table 2. Methods of precipitation based on chemical reactions [21,22].

\begin{tabular}{ll}
\hline Precipitation Methods & Reaction \\
\hline Hydrolysis precipitation & $\mathrm{Me}^{\mathrm{n}+}+\mathrm{nOH}^{-} \rightarrow \mathrm{Me}(\mathrm{OH})_{\mathrm{n}(\mathrm{s})}$ \\
Sulfide precipitation & $\mathrm{Co}^{2+}+\mathrm{S}^{2-} \rightarrow \mathrm{NiS}_{(\mathrm{s})}$ \\
& $\mathrm{Cu}^{2+}+\mathrm{S}^{2-} \rightarrow \mathrm{CuS}_{(\mathrm{s})}$ \\
& $\mathrm{Ni}^{2+}+\mathrm{S}^{2-} \rightarrow \mathrm{NiS}_{(\mathrm{s})}$ \\
\hline \multirow{5}{*}{ Inorganic acid anions precipitation } & $\mathrm{Cr}^{3+}+\mathrm{PO}_{4}{ }^{3-} \rightarrow \mathrm{CrPO}_{4(\mathrm{~s})}$ \\
& $\mathrm{Li}^{+}+\mathrm{CO}_{3}^{2-} \rightarrow \mathrm{Li}_{2} \mathrm{CO}_{3(\mathrm{~s})}$ \\
& $\mathrm{Ca}^{2+}+\mathrm{SO}_{4}^{2-} \rightarrow \mathrm{SaSO}_{4}{ }^{2-} \rightarrow \mathrm{CaSO}_{4(\mathrm{~s})}$ \\
\hline \multirow{2}{*}{ Organic acid anions precipitation } & $\mathrm{Y}^{3+}+\mathrm{C}_{2} \mathrm{O}_{4}{ }^{2-} \rightarrow \mathrm{Y}_{2}\left(\mathrm{C}_{2} \mathrm{O}_{4}\right)_{3(\mathrm{~s})}$ \\
& $\mathrm{Co}^{3+}+\mathrm{C}_{4} \mathrm{H}_{9} \mathrm{OCSS}^{-} \rightarrow \mathrm{Co}\left(\mathrm{C}_{4} \mathrm{H}_{9} \mathrm{OCSS}_{3(\mathrm{~s})}\right.$ \\
\hline \multirow{2}{*}{ Base salts precipitation } & $\mathrm{K}^{+}+3 \mathrm{Fe}^{3+}+2 \mathrm{HSO}_{4}{ }^{-}+6 \mathrm{H}_{2} \mathrm{O} \rightarrow \mathrm{KFe}_{3}\left(\mathrm{SO}_{4}\right)_{2}(\mathrm{OH})_{6(\mathrm{~s})}+4 \mathrm{H}^{+}$ \\
& $2 \mathrm{Fe}^{3+}+4 \mathrm{H}_{2} \mathrm{O} \rightarrow 2 \mathrm{FeOOH}_{(\mathrm{s})}+6 \mathrm{H}^{+}$ \\
\hline
\end{tabular}

As for aqueous crystallization methods, they can be classified based on the method of generating supersaturation. The main methods are listed in Table 3.

\subsection{Li-Ion Battery Materials and Metal Salts Used in Their Synthesis}

In Li-ion batteries, lithium ions move from the anode through an electrolyte to the cathode during discharge, and back during charge [32]. The cathode material is made of a powdered intercalated lithium compound. Layered oxides $\mathrm{LiMO}_{2}$ or spinel type $\mathrm{LiM}_{2} \mathrm{O}_{4}$ compounds (lithium-containing transition metal oxides, with $M=\mathrm{Co}, \mathrm{Ni}, \mathrm{Mn}$ of different composition) have mostly been used, but also $\mathrm{LiMPO}_{4}$ compounds are increasingly popular. The anode material typically consists of powdered carbon, such as graphite. It is bonded with respective foils ( $\mathrm{Cu}$ foil or Al foil) in the battery. The electrolyte consists of a salt of lithium and a non-coordinating anion $\left(\mathrm{PF}_{6}{ }^{-}, \mathrm{BF}_{4}{ }^{-}, \mathrm{CF}_{3} \mathrm{SO}_{3}{ }^{-}\right.$, or $\left.\mathrm{N}\left(\mathrm{SO}_{2} \mathrm{CF}_{3}\right)_{2}{ }^{-}\right)$dissolved in a polar organic solvent [32-34]. Table 4 lists some representative electrode materials that have been commercialized or have commercial prospects in rechargeable Li-ion batteries. Doping and coating have also been used to improve the performance of anode or cathode materials in 
Li-ion batteries [34]. Assuming Co as the transition metal in the cathode material, the overall discharge reaction can be written as [32]:

$$
\mathrm{Li}_{1-x} \mathrm{CoO}_{2}+\mathrm{Li}_{x} \mathrm{C}_{6} \rightarrow \mathrm{LiCoO}_{2}+\mathrm{C}_{6} ;(x \text { is between } 0 \text { and } 1)
$$

Table 3. Methods of crystallization by method of supersaturation generation.

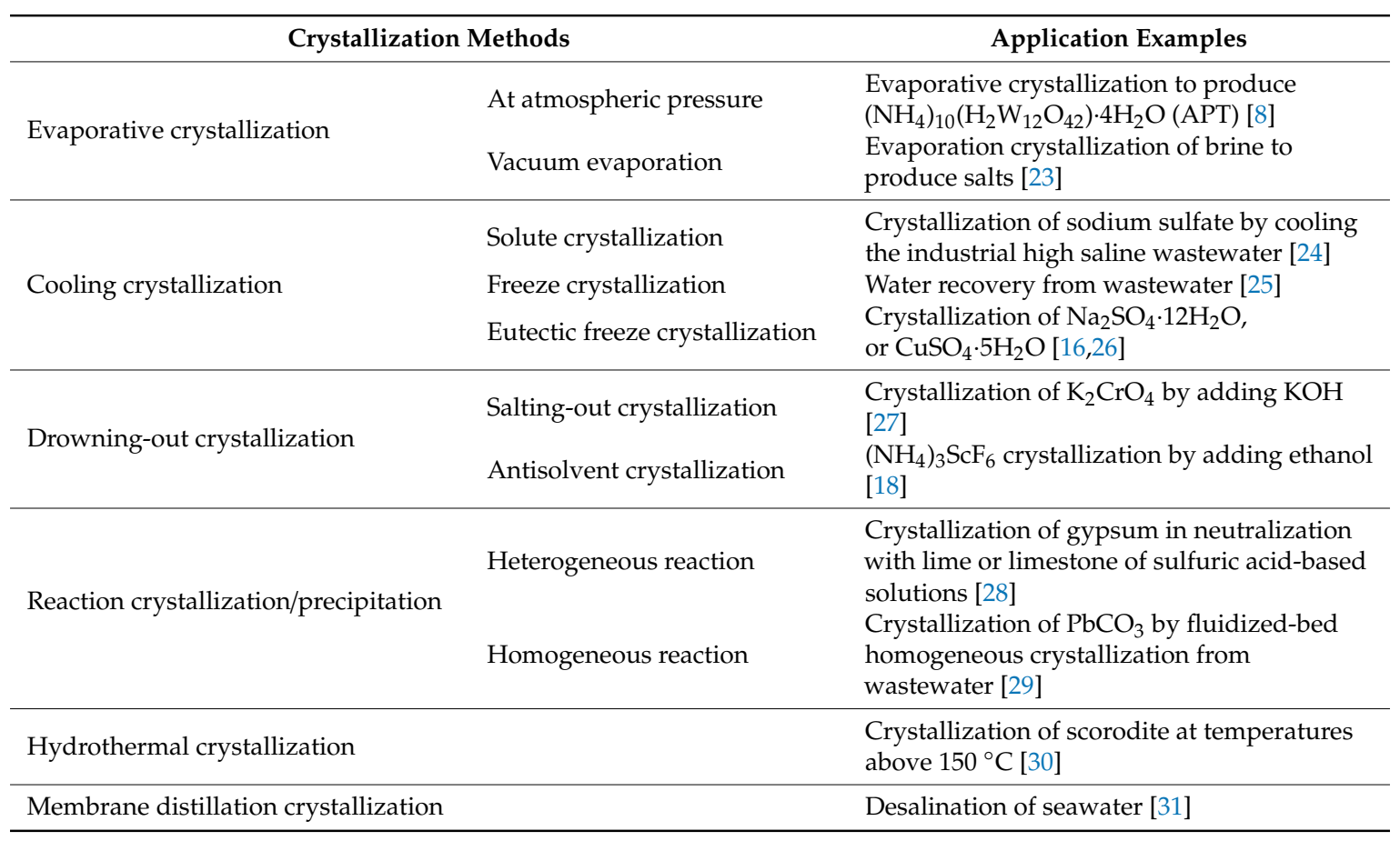

Table 4. List of representative electrode materials in rechargeable Li-ion batteries [32-38].

\begin{tabular}{lll}
\hline \multicolumn{1}{c}{ Cathode } & $\begin{array}{l}\text { Electrolyte (Lithium Salts in } \\
\text { Organic Carbonates) }\end{array}$ & Anode \\
\hline $\mathrm{LiCoO}_{2}(\mathrm{LCO})$ & $\mathrm{LiPF}_{6}$ & Graphite \\
$\mathrm{LiMn}_{2} \mathrm{O}_{4}(\mathrm{LMO})$ & $\mathrm{LiBF}_{4}$ & $\mathrm{Li}-\mathrm{M}(\mathrm{M}=\mathrm{Si}, \mathrm{Ge}, \mathrm{Sn})$ alloys \\
$\mathrm{LiNi}_{x} \mathrm{Co}_{y} \mathrm{Mn}_{(1-x-y)} \mathrm{O}_{2}(\mathrm{NCM})$ & $\mathrm{LiAsF}_{6}$ & $\mathrm{Nano}-\mathrm{Si} / \mathrm{C}$ \\
$\mathrm{LiNi}_{x} \mathrm{Co}_{y} \mathrm{Al}(1-x-y) \mathrm{O}_{2}(\mathrm{NCA})$ & $\mathrm{LiN}_{\left(\mathrm{SO}_{2} \mathrm{CF}_{3}\right)_{2}}$ & Carbon nanotubes \\
$\mathrm{LiFePO}_{4}(\mathrm{LFP})$ & $\mathrm{LiSO}_{3} \mathrm{CF}_{3}$ & $\mathrm{Li}_{4} \mathrm{Ti}_{5} \mathrm{O}_{12}, \mathrm{Li}_{2} \mathrm{Ti}_{3} \mathrm{O}_{7}, \mathrm{Li}_{2} \mathrm{TiO}_{3}$, or $^{\mathrm{LiTiO}} \mathrm{Li}_{2}$ \\
$\mathrm{Li}_{2} \mathrm{TiO}_{3}$ & - & - \\
\hline
\end{tabular}

In Li-ion batteries, the constrained specific capacity of the cathode materials is one of the major obstacles to improving the energy density. The synthesis cost of cathode materials can be high as some of the oxides require critical metals and the synthesis processes usually require elevated temperatures. Important synthesis methods of cathode materials include the solid state reaction method, the co-precipitation method, the sol-gel method, hydrothermal synthesis, and spray pyrolysis [39,40]. In most cases, metal salts serve as raw materials for the cathode materials. Using NCM as an example, Figures 1 and 2 show typical synthesis processes. 


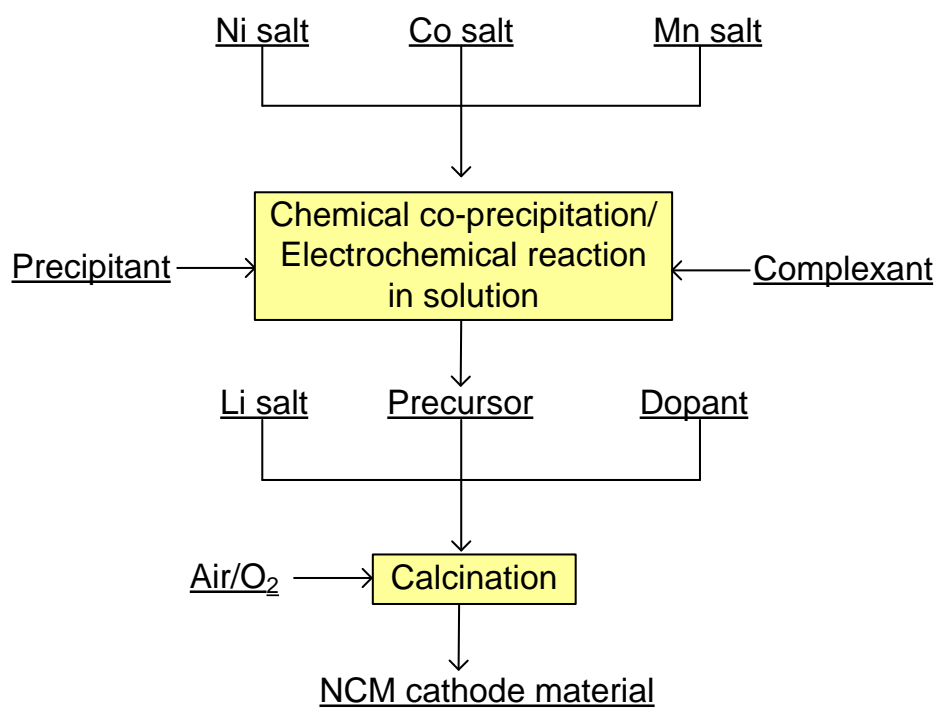

Figure 1. The common flowchart for the synthesis of NCM cathode material.

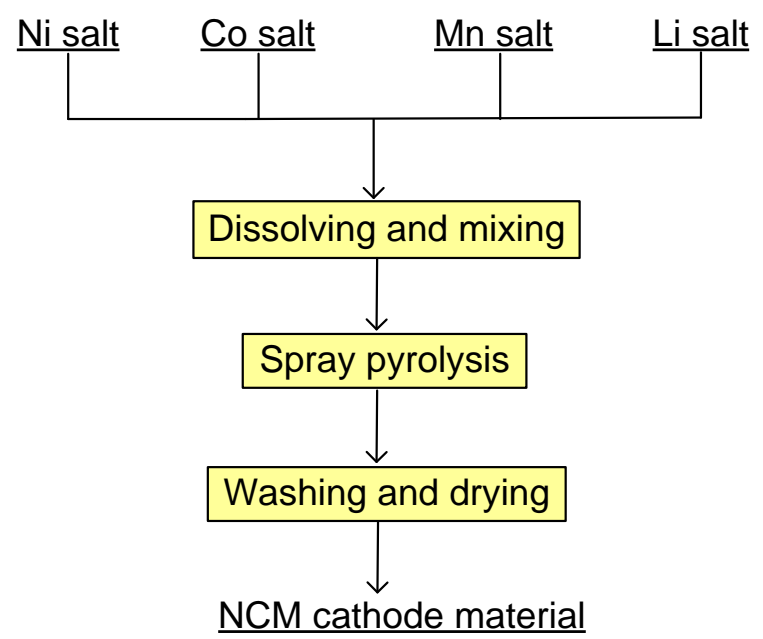

Figure 2. Flowchart for the synthesis of NCM cathode material using the spray pyrolysis method.

Common metal salts (or metal compounds) for cathode materials are listed in Table 5. The production of these raw materials is the upstream part of Li-ion battery manufacture. Hydrometallurgical processes are necessary for their production, and precipitation and crystallization are essential steps of the processes. Purity requirements of battery grade $\mathrm{Li}_{2} \mathrm{CO}_{3}, \mathrm{CoSO}_{4} \cdot 7 \mathrm{H}_{2} \mathrm{O}$, $\mathrm{NiSO}_{4} \cdot 6 \mathrm{H}_{2} \mathrm{O}$ and $\mathrm{MnSO}_{4} \cdot \mathrm{H}_{2} \mathrm{O}$, which are the most common commercial products, are reported to be (by mass) $\mathrm{Li}_{2} \mathrm{CO}_{3} \geq 99.5 \%, \mathrm{Co} \geq 20.2 \%, \mathrm{Ni} \geq 22.0 \%$ and $\mathrm{Mn} \geq 31.8 \%$ [ 41$]$.

Table 5. Metal salts (or metal compounds) used in the production of cathode materials [36,39-43].

\begin{tabular}{lllllll}
\hline Lithium & Cobalt & Nickel & Manganese & Titanium & Aluminum & Iron \\
\hline $\mathrm{Li}_{2} \mathrm{CO}_{3}$ & $\mathrm{CoSO}_{4} \cdot 7 \mathrm{H}_{2} \mathrm{O}$ & $\mathrm{NiSO} \cdot 6 \mathrm{H}_{2} \mathrm{O}$ & $\mathrm{MnSO}_{4} \cdot \mathrm{H}_{2} \mathrm{O}$ & $\mathrm{TiO}_{2}$ & $\mathrm{Al}\left(\mathrm{NO}_{3}\right)_{3} \cdot 9 \mathrm{H}_{2} \mathrm{O}$ & $\mathrm{FePO}$ \\
$\mathrm{LiOH}$ & $\mathrm{Co}_{3} \mathrm{O}_{4}$ & $\mathrm{Ni}(\mathrm{OH})_{2}$ & $\mathrm{MnO}_{2}$ & $\mathrm{Ti}$ & - & $\mathrm{Fe}\left(\mathrm{NO}_{3}\right)_{3}$ \\
$\mathrm{LiCH}_{3} \mathrm{COO}$ & $\mathrm{Co}\left(\mathrm{CH}_{3} \mathrm{COO}\right)_{2}$ & $\mathrm{NiO}$ & $\mathrm{Mn}\left(\mathrm{NO}_{3}\right)_{2}$ & - & - & $\mathrm{FeC}_{2} \mathrm{O}_{4}$ \\
$\mathrm{LiNO}_{3}$ & $\mathrm{Co}\left(\mathrm{NO}_{3}\right)_{2}$ & $\mathrm{Ni}\left(\mathrm{NO}_{3}\right)_{2}$ & $\mathrm{Mn}\left(\mathrm{CH}_{3} \mathrm{COO}\right)_{2}$ & - & - & - \\
\hline
\end{tabular}

An increasingly important route for the production of metal salts is from secondary sources, such as spent Li-ion batteries. Recovering the metals from Li-ion batteries reduces their environmental impact and may increase the availability of critical elements. 


\section{Precipitation and Crystallization of Metal Salts for Li-Ion Battery Materials}

For the production of the metal salts mentioned in Table 5, the raw materials include some minerals and natural salt lake brine and some secondary resources, such as spent Li-ion batteries, waste residue, slag and tailings. The main minerals and natural brine are $[1,3,8]$ :

Lithium: lepidolite, spodumene, petalite, lithiophosphate and salt lake brine.

Cobalt: cobalt sulfide minerals and cobalt oxide minerals.

Nickel: laterite, nickel sulfide minerals and nickel arsenide mineral.

Manganese: pyrolusite, psilomelane, braunite and rhodochrosite.

Hydrometallurgical processing is an important part in the process of utilizing these resources, and in general, the process can be summarized as pretreatment $\rightarrow$ leaching $\rightarrow$ separation/purification $\rightarrow$ product precipitation/crystallization [3]. Common techniques for the separation or purification unit include selective precipitation, solvent extraction, ion exchange and reverse osmosis. The concentration of metal ions in the streams from the separation or purification unit is relatively high. Precipitation or crystallization is then used to produce the final products of high purity. The sulfate system is most commonly used in the hydrometallurgical processes due to the low cost of sulfuric acid, leading to metal sulfate salts as the resulting products. Other salts can also be produced from these products.

\subsection{Evaporative Crystallization}

Figure 3 shows a phase diagram that summarizes the product crystallization routes followed by the methods discussed in this review for a generic binary salt-water system. Point A represents the starting composition and temperature of a batch solution. Evaporative crystallization (EC) is often employed to produce supersaturation via evaporation of the solvent at elevated temperature, which is represented by the process path $\mathrm{A} \rightarrow \mathrm{B} \rightarrow \mathrm{C}$ in Figure 3 .

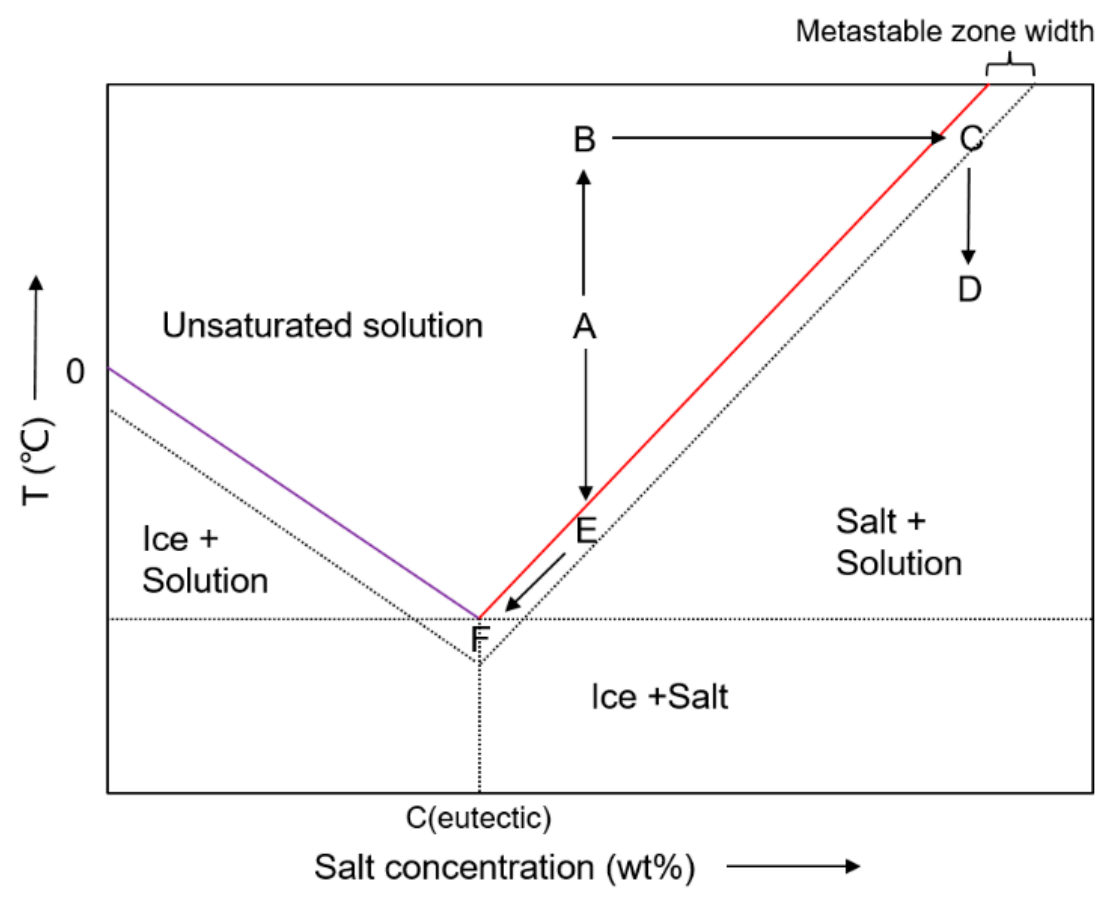

Figure 3. Phase diagram of a binary salt-water system.

EC is a conventional and widely used unit operation for industrial crystallization of many products, including metal salts for Li-ion battery materials as detailed above [44]. This process can attain relatively high crystal growth rates, as a result of the high temperatures employed, but it is not an energy-efficient process [45]. 
If the solubility of a solute is appreciably decreased by a reduction in temperature, evaporation is always followed by a cooling operation that can significantly increase the yield at low cost [44]. Then the process path is $\mathrm{A} \rightarrow \mathrm{B} \rightarrow \mathrm{C} \rightarrow \mathrm{D}$ as shown in Figure 3. Figure 4 shows the solubility curves of $\mathrm{Li}_{2} \mathrm{SO}_{4}, \mathrm{CoSO}_{4}, \mathrm{MnSO}_{4}$ and $\mathrm{NiSO}_{4}$ in $\mathrm{H}_{2} \mathrm{O}$. As can be seen, for $\mathrm{CoSO}_{4}$ and $\mathrm{NiSO}_{4}, \mathrm{EC}$ normally consists of solute concentration by evaporation and crystallization after cooling. The products are sulfate hydrates.

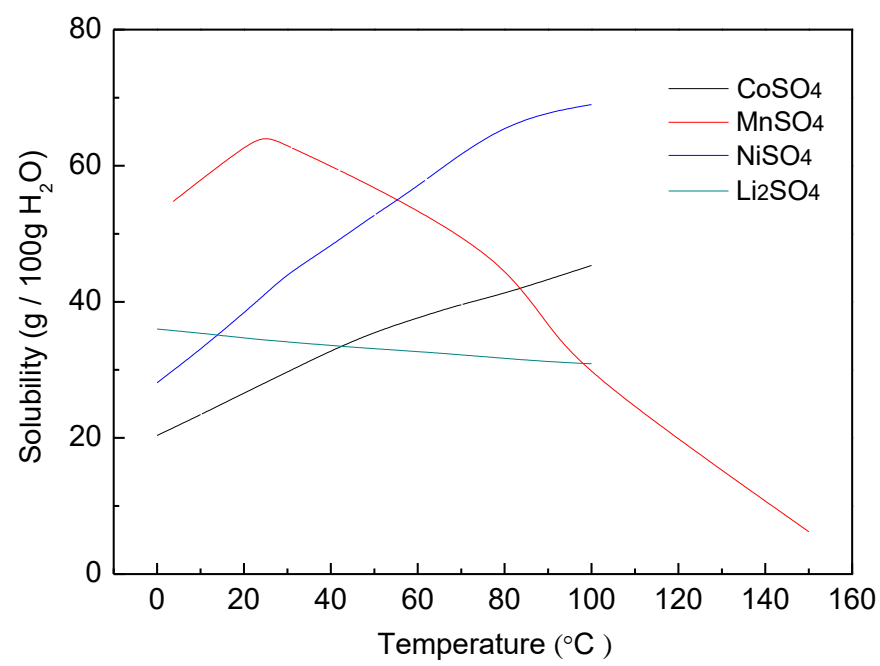

Figure 4. Solubility curves of $\mathrm{CoSO}_{4}, \mathrm{MnSO}_{4}, \mathrm{NiSO}_{4}$ and $\mathrm{Li}_{2} \mathrm{SO}_{4}$ in $\mathrm{H}_{2} \mathrm{O}$ (solubility data based on literature reports [46]).

Multi-effect evaporative crystallization (MEEC) is the most frequently used EC technique. Figure 5 shows a triple-effect evaporative crystallization system. It consists of three evaporators in series and a final condenser. Compared to the single-effect evaporative system, MEEC has the advantages of lower energy consumption and higher crystallization rates, but it constitutes a complex operation [47].

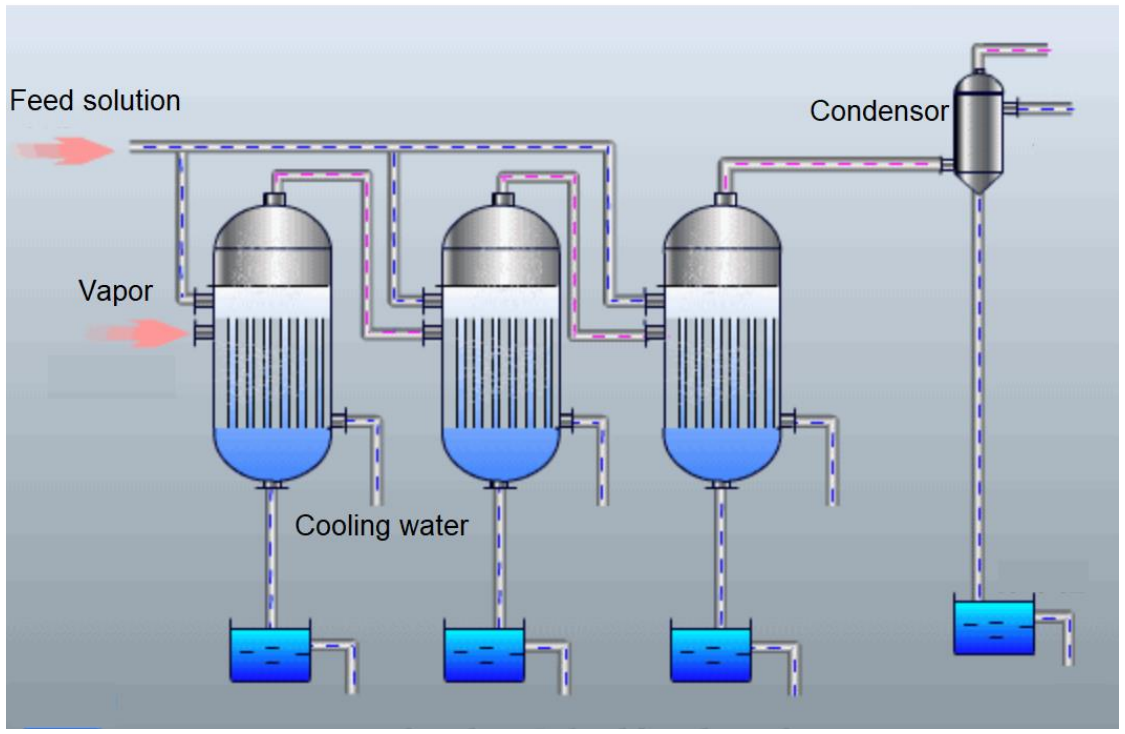

Figure 5. Schematic diagram of a triple effect evaporation crystallization system.

An alternative to multiple-effect evaporation is vapor recompression. The principle of this method is to raise the temperature of the vapor as it exits the evaporator by raising its pressure, and passing it 
back into the evaporator heat exchanger. However, this method has not been widely applied, because it lacks reliability and is not applicable to systems with high boiling point components [48].

\subsection{Eutectic Freeze Crystallization}

Eutectic freeze crystallization (EFC) produces supersaturation and attains the specific eutectic conditions through both freeze crystallization and crystallization by concentration [49]. This process is represented by the path $\mathrm{A} \rightarrow \mathrm{E} \rightarrow \mathrm{F}$ shown in Figure 3. EFC is a suitable technology for the simultaneous separation of an aqueous solution into ice and salt crystals near the eutectic point [50]. The composition of the feed solution can be either higher or lower than the concentration at the eutectic point F. Ideally, separation of the resulting ice and salt crystals can then be achieved through gravity, as ice has a lower density but salt crystals have a higher density than the solution. Particular advantages of EFC include the ability to recover pure water and treat corrosive streams due to the low temperatures employed. Also, EFC requires significantly less energy input than EC, since the heat of fusion of ice $(6.01 \mathrm{~kJ} / \mathrm{mol})$ is six times lower than the heat of evaporation of water $(40.65 \mathrm{~kJ} / \mathrm{mol})$ [51]. However, EFC requires higher capital costs than $\mathrm{EC}$, since the technique is not currently mature.

EFC has been widely studied for the treatment of wastewater and the desalination of brine. Salt crystals that have been targeted include $\mathrm{Na}_{2} \mathrm{SO}_{4} \cdot 10 \mathrm{H}_{2} \mathrm{O}, \mathrm{MgSO}_{4} \cdot 7 \mathrm{H}_{2} \mathrm{O}, \mathrm{CaSO}_{4} \cdot 7 \mathrm{H}_{2} \mathrm{O}, \mathrm{Na}_{2} \mathrm{CO}_{3}, \mathrm{NaCl}$, $\mathrm{NaNO}_{3}$ and $\mathrm{KNO}_{3}$, where the metals are commonly found in saline wastewater [52-55]. Research into the recovery and purification of other salts from industrial streams using EFC has so far been limited, but is attracting increased attention.

EFC could be a promising approach for the production of metal salts for Li-ion battery materials. However, the application of EFC for recovery of $\mathrm{Li}, \mathrm{Co}, \mathrm{Mn}$ has not yet been reported. $\mathrm{Lu}$ [50] studied the use of EFC for recovery of $\mathrm{NiSO}_{4} \cdot 7 \mathrm{H}_{2} \mathrm{O}$ from an industrial $\mathrm{NiSO}_{4}$ solution containing $\mathrm{Na}_{2} \mathrm{SO}_{4}$, reporting that $70 \% \mathrm{NiSO}_{4}$ could be crystallized from solution before it became saturated with $\mathrm{Na}_{2} \mathrm{SO}_{4}$. Figure 6 shows the binary phase diagram of the $\mathrm{NiSO}_{4}-\mathrm{H}_{2} \mathrm{O}$ system at low temperatures. As can be seen, the eutectic temperature of the pure $\mathrm{NiSO}_{4}$ solution is about $-4{ }^{\circ} \mathrm{C}$. All systems are unique, however, so more research is necessary to ensure efficacious production of $\mathrm{Li}, \mathrm{Ni}, \mathrm{Co}$ and $\mathrm{Mn}$ salts through EFC.

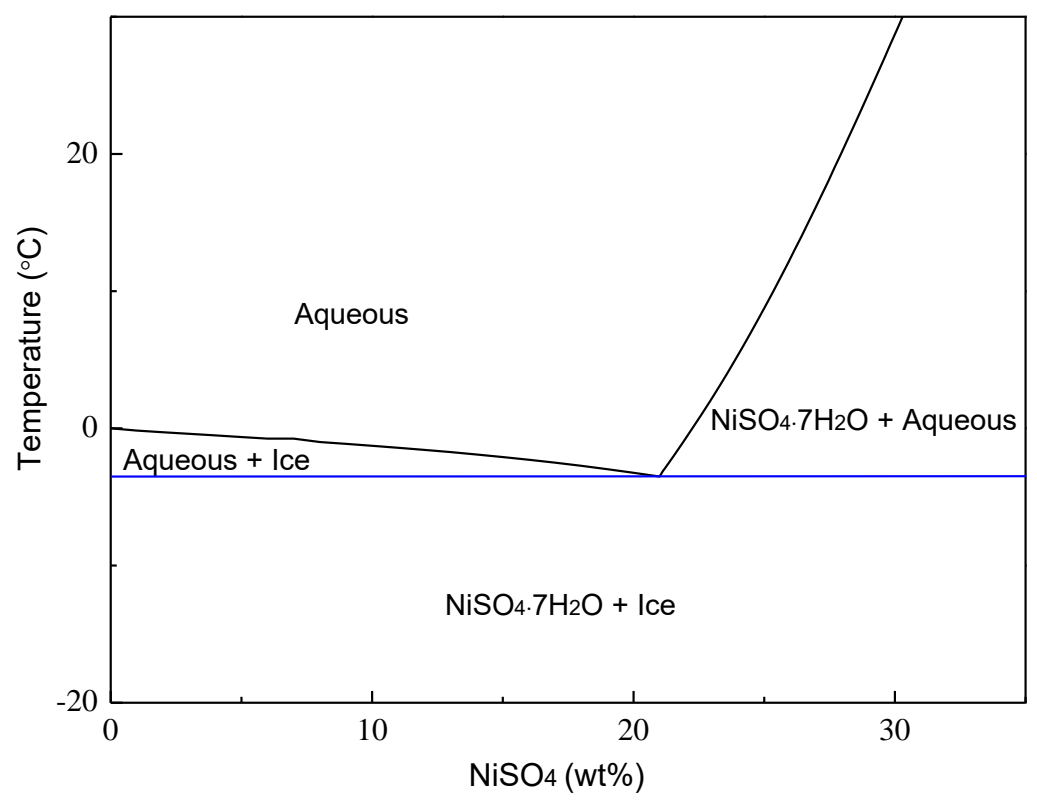

Figure 6. Binary phase diagram of the $\mathrm{NiSO}_{4}-\mathrm{H}_{2} \mathrm{O}$ system (solubility data based on literature reports $[46,56])$. 
In order to make the EFC process more efficient, column crystallizers capable of simultaneously crystallizing and separating ice and salt crystals have been designed [51]. Figure 7 shows a typical cylindrical crystallization unit for this EFC process. The temperature of the system is controlled by indirect cooling. The scraping operation is very important during the EFC process, because the scrapers dislodge crystals of ice or inorganic salts from the chilled surface. This avoids salt or ice scaling on the chilled surfaces and promotes crystal growth in the bulk of the solution. This in turn allows the ice and salt crystals to be separated on the basis of the difference in densities.

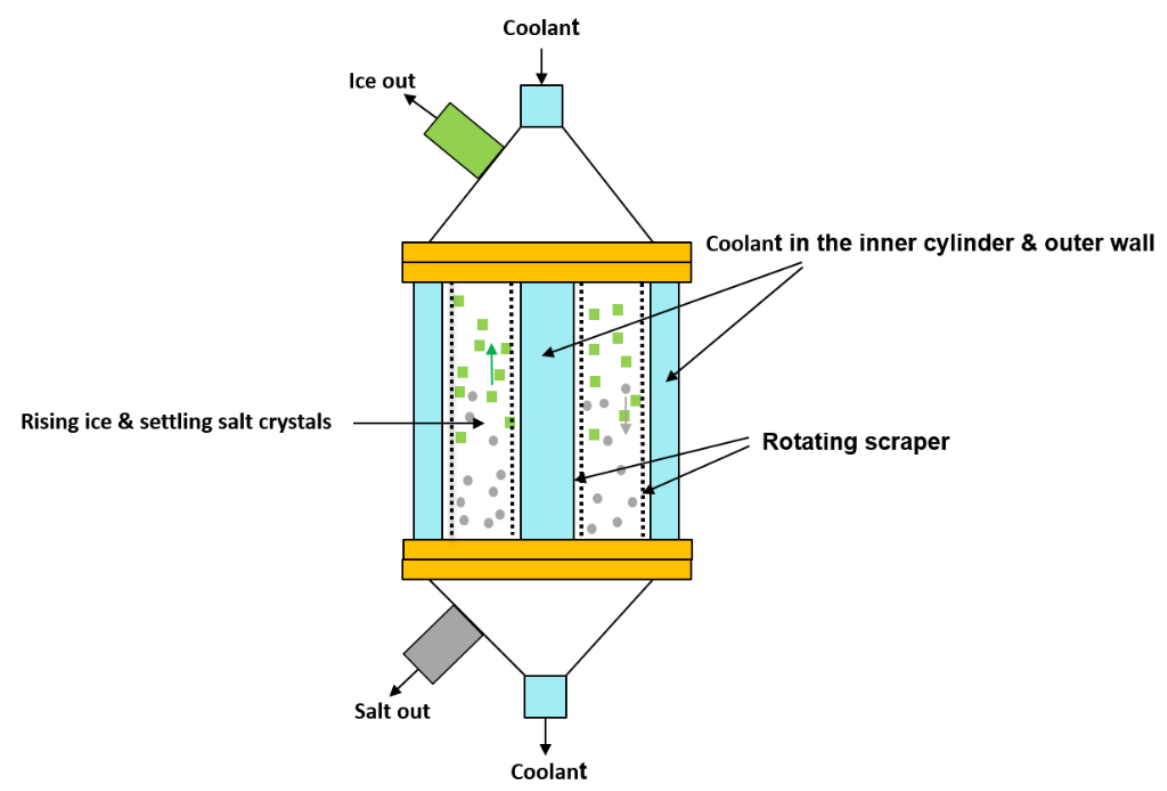

Figure 7. Schematic diagram of a cylindrical chilling module crystallizing unit for EFC, as described by Vaessen et al. [57].

\subsection{Antisolvent Crystallization}

Antisolvent crystallization relies on the addition of a water-miscible organic solvent to reduce the solubility of the solute, generating supersaturation, and thereby forcing the targeted salts to crystallize $[58,59]$. The ability of a solvent to solubilize an ion can be captured by the dielectric constant $(\varepsilon)$ of the solvent. The dielectric constant is a measure of the polarizability of a substance. If the dielectric constant of the additional solvent is lower than that of water, the solvation of the charged ions is decreased, and the solubility of the solute is reduced [60]. Antisolvent crystallization can produce high product yields over narrow temperature ranges [61]. It is also an energy saving and highly safe technique because the process can be executed at ambient temperature. In addition, comparatively simple equipment is required for antisolvent crystallization, which is thus attractive from both cost and safety perspectives. However, antisolvent crystallization requires large capital cost due to handling large volumes [49], and the recovery of antisolvent after crystallization introduces extra costs.

The literature on antisolvent crystallization contains numerous reports of potential organic solvents that are able to lower the solubility of some inorganic solutes. These include ethanol, acetic acid, 2-propanol, acetone, glycine, methanol, tert-butanol, methyl-ethyl-ketone (MEK), ethyl-acetate and isopropyl-acetate $[17,18,59,61]$. Recently, antisolvent crystallization has been examined for use in the selective recovery of critical metals from aqueous solutions. For example, Korkmaz et al. used antisolvent crystallization to selectively recover rare earth elements from NiMH battery leach liquors [17]. The antisolvents used in this case were ethanol and 2-propanol. Kaya et al. [18] reported on the recovery of scandium from an ammonium fluoride strip liquor using antisolvent crystallization. In this instance, the recovery yields were above 98\% when acetone, ethanol, methanol or isopropanol were used. Antisolvent crystallization could also be used to recover Li, Ni, Co and Mn salts [62]. 
An antisolvent crystallization process using a LiOH-water-ethanol system has been reported to produce purified $\mathrm{LiOH} \cdot \mathrm{H}_{2} \mathrm{O}$ [63]. Research by Cohen et al. first suggested that antisolvent crystallization could be used to recover $\mathrm{NiSO}_{4}$ from hydrometallurgical decopperized electrolytes [64]. Moldoveanu and Demopoulos [59] studied antisolvent crystallization for several metal sulfate and chloride systems of hydrometallurgical interest. It was concluded that 2-propanol is an efficient solvent for many metal sulfates and $>90 \%$ crystallization yields under ambient conditions were reported, but the process was found to be ineffective for chloride systems [59]. The antisolvent could be recovered from the aqueous solution after crystallization and reused, e.g., by reduced pressure distillation $[17,18]$.

In general, despite the many potential applications for antisolvent crystallization in inorganic processing, wastewater treatment and hydrometallurgy, further systematic study of the process is needed, as only limited data and a low number of studies have been reported and only for specific systems.

\subsection{Precipitation (Reaction Crystallization)}

As summarized in the Introduction, in the field of hydrometallurgy, reaction crystallization is usually referred to simply as 'precipitation'. Metal precipitation is a process in which the metal ion is allowed to react with other compounds to produce a product of low solubility. Metal precipitation is the most common method to recover metals as nearly insoluble compounds from solution [1]. $\mathrm{Li}_{2} \mathrm{CO}_{3}$ is the common source of lithium when producing cathode materials for Li-ion batteries [10]. Precipitation is always employed to produce $\mathrm{Li}_{2} \mathrm{CO}_{3}$, since it is practically insoluble in neutral or basic aqueous solution. Anions for precipitation of $\mathrm{Ni}^{2+}, \mathrm{Co}^{2+}$ and $\mathrm{Mn}^{2+}$ could be $\mathrm{OH}^{-}, \mathrm{C}_{2} \mathrm{O}_{4}{ }^{2-}, \mathrm{CO}_{3}{ }^{2-}, \mathrm{S}^{2-}$ and $\mathrm{PO}_{4}{ }^{3-}$ [22]. For example, $\mathrm{CoC}_{2} \mathrm{O}_{4} \cdot 2 \mathrm{H}_{2} \mathrm{O}$ with a purity of $97.47 \%$ was produced by Chen et al. using precipitation after solvent extraction [65]. Dhiman et al. studied the selective precipitation of $\mathrm{Ni}^{2+}$ by adding $10 \%$ dimethylglyoxime $\left(\mathrm{dmgH}_{2}\right)$, after which $\mathrm{Ni}(\mathrm{OH})_{2}$ was prepared as a final product [66]. However, this process is generally used to produce crude products or precursors, because high product purity cannot be obtained using conventional precipitation methods.

A key issue with this method is that the precipitate formed by the addition of precipitating agents is typically not easily filtered, because the local supersaturation at the feed point where the reagent is added will generally be very high [67]. In order to improve the quality of the precipitate, the level of supersaturation should be kept low during the chemical reaction. Homogeneous precipitation can accomplish this. In homogeneous precipitation reaction, the precipitating agent is produced over a long period of time in a homogeneous solution [1]. The resulting precipitate is compact and crystalline. Methods employed for controlling supersaturation include $\mathrm{pH}$ control, metal complexation and dissociation, dissolution reaction, and redox reaction [2]. Homogeneous precipitation could also be used to produce metal salts (or metal compounds) for Li-ion battery materials. For example, highly pure $\mathrm{Co}(\mathrm{OH})_{2}$ can be prepared by adding $\mathrm{NaOH}$ to a mixed solution of ammonia and cobalt sulfate, because $\mathrm{Co}^{2+}$ forms complex compounds with $\mathrm{NH}_{3}$ and then dissociates in a controlled manner [68].

\subsection{Other Methods}

Hydrothermal crystallization can sometimes be used to produce metal salts for Li-ion battery materials. As seen in Figure 4, the solubility of $\mathrm{MnSO}_{4}$ at high temperature is very low, so that $\mathrm{MnSO}_{4}$ hydrate crystals can be produced in an autoclave [3]. Another potential method is membrane distillation crystallization. This is a hybrid process of distillation and crystallization. Membrane distillation can separate the water from the concentrated solution, to produce a supersaturated solution for subsequent crystallization [31]. The current applications of membrane distillation crystallization are limited to protein crystallization and few wastewater treatments [31]. Further research into membrane distillation crystallization is needed to elucidate the best processes for the production of metal salts. 


\section{Precipitation and Crystallization in Hydrometallurgical Recycling of Li-Ion Batteries}

With the ever-growing need for lithium-ion batteries, particularly from the electric mobility industry, a large amount of lithium-ion batteries are bound to be retired in the near future, thereby leading to serious disposal problems and detrimental impacts on environment and energy conservation [69]. A complete recycling process of Li-ion batteries includes physical treatment and pyrometallurgical/hydrometallurgical chemical process due to the complicated assembly of Li-ion batteries and the diversity of electrode materials [69,70]. In recycling of Li-ion batteries, the foils of $\mathrm{Cu}$ and $\mathrm{Al}$ and the anode material are easily physically separated. The composition of the cathode material is complex, and rich in valuable metals, and thus a key to a viable recycling is to "close the loop" with respect to the cathode material [10]. The recovery of cathode material using a hydrometallurgical process has been widely studied $[6,10,65,66,69,70]$. Figure 8 shows a general flowchart for the hydrometallurgical process for recycling Li-ion batteries. Some specific and detailed flowcharts have been investigated in literature [10,71,72]. Moreover, diversity in design and products is presented in the hydrometallurgical processes and some industrial-scale production have been achieved [73-75]. Relevant metal salts or precursors of cathode material are the main products of the recycling processes [71-75]. For example, in Recupyl (France) process [73] and AEA (UK) process [75], all the valuable metals have been recycled as metal salts.

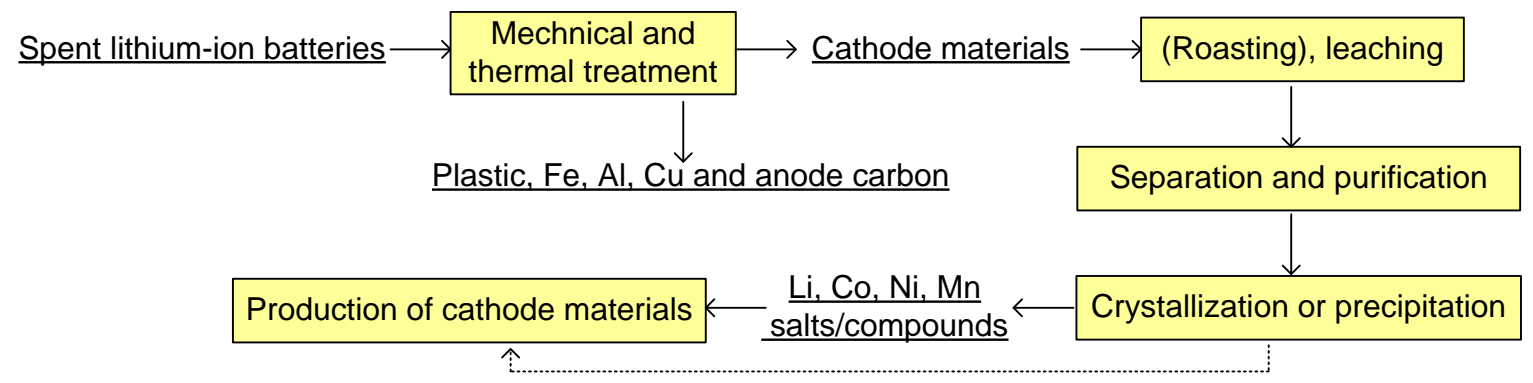

Figure 8. General flowchart for the hydrometallurgical process for recycling of Li-ion batteries.

As can be seen in Figure 8, after obtaining the cathode materials from spent Li-ion batteries, pretreatment, such as roasting, alkaline leaching and acid leaching are employed to solubilize the metals. Alkaline leaching is performed for materials with a high Al content, while acid leaching is always necessary for the recovery of $\mathrm{Li}, \mathrm{Ni}, \mathrm{Co}$ and $\mathrm{Mn}$ [72]. After obtaining the acidic leach solution, various processes, which have similar steps and methods, have been developed to achieve separation and purification [66,71]. It is possible to resynthesize cathode materials directly from strip or leach solutions in the lab after careful adjustment of the conditions (dosing of salts and evaporation) [76,77]. However, the need for careful control of the conditions in the presence of impurities makes it challenging to develop a robust and efficient industrial process for direct synthesis of new cathode materials.

Figure 9 shows a general flowchart for the treatment of acidic leach solutions. Precipitation, crystallization, solvent extraction and electrolysis deposition techniques can be employed. The precipitation and crystallization processes involved are mainly for the removal of $\mathrm{Al}$ and $\mathrm{Fe}$, and the separation and production of $\mathrm{Li}, \mathrm{Ni}, \mathrm{Co}$ and $\mathrm{Mn}$ salts. It is noteworthy that some mixed metal salts produced in hydrometallurgical processes with no purification stages can also be used for the production of new materials $[78,79]$. Table 6 summarizes some precipitation and crystallization techniques used in the recycling of Li-ion batteries. 


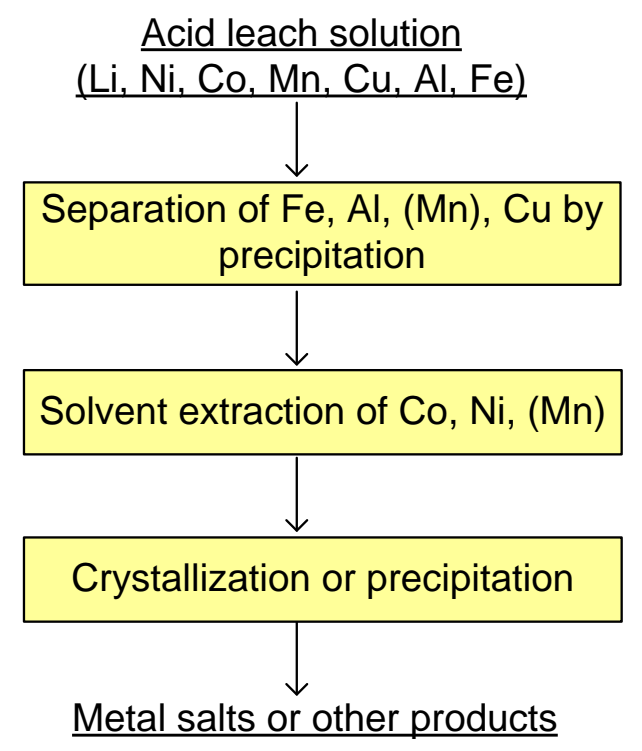

Figure 9. General flowchart for metal recovery from acidic leach solution of cathode materials.

Table 6. Summary of precipitation and crystallization methods used in the recycling of Li-ion batteries.

\begin{tabular}{|c|c|c|c|}
\hline Element & Process & Chemical Reaction & References \\
\hline $\mathrm{Cu}$ & Precipitation (cementation) with Fe & $\mathrm{Cu}^{2+}+\mathrm{Fe} \rightarrow \mathrm{Cu}_{(\mathrm{s})}+\mathrm{Fe}^{2+}$ & [10] \\
\hline \multirow{4}{*}{$\mathrm{Fe}$} & Precipitation of $\mathrm{Fe}(\mathrm{OH})_{3}{ }^{1}$ & $\mathrm{Fe}^{3+}+3 \mathrm{OH}^{-} \rightarrow \mathrm{Fe}(\mathrm{OH})_{3(\mathrm{~s})}$ & [66] \\
\hline & Precipitation of $\mathrm{FeOOH}$ & $4 \mathrm{Fe}^{2+}+\mathrm{O}_{2}+6 \mathrm{H}_{2} \mathrm{O} \rightarrow 4 \mathrm{FeOOH}_{(\mathrm{s})}+8 \mathrm{H}^{+}$ & [10] \\
\hline & Precipitation of $\mathrm{Na}_{2} \mathrm{Fe}_{6}\left(\mathrm{SO}_{4}\right)_{4}(\mathrm{OH})_{12}$ & $6 \mathrm{Fe}^{3+}+12 \mathrm{H}_{2} \mathrm{O}+2 \mathrm{Na}^{+}+4 \mathrm{SO}_{4}{ }^{2-}$ & [76] \\
\hline & (sodium jarosite) & $\rightarrow \mathrm{Na}_{2} \mathrm{Fe}_{6}\left(\mathrm{SO}_{4}\right)_{4}(\mathrm{OH})_{12(\mathrm{~s})}+12 \mathrm{H}^{+}$ & \\
\hline $\mathrm{Al}$ & Precipitation of $\mathrm{Al}(\mathrm{OH})_{3}$ & $\mathrm{Al}^{3+}+3 \mathrm{OH}^{-} \rightarrow \mathrm{Al}(\mathrm{OH})_{3(\mathrm{~s})}$ & {$[66]$} \\
\hline \multirow{4}{*}{ Mn } & Evaporation crystallization of $\mathrm{MnSO}_{4} \cdot \mathrm{H}_{2} \mathrm{O}$ & N/A & [76] \\
\hline & Precipitation of $\mathrm{Mn}(\mathrm{OH})_{2}$ or & $\mathrm{Mn}^{2+}+2 \mathrm{OH}^{-} \rightarrow \mathrm{Mn}(\mathrm{OH})_{2(\mathrm{~s})}$ & [10] \\
\hline & Precipitation of MnS or Ni-Co-Mn sulfide & $\mathrm{Mn}^{2+}+\mathrm{S}^{2-} \rightarrow \mathrm{MnS}_{(\mathrm{s})}$ & [10] \\
\hline & Precipitation of $\mathrm{MnO}_{2}$ & $\mathrm{Mn}^{2+}+\mathrm{S}_{2} \mathrm{O}_{8}{ }^{2-}+2 \mathrm{H}_{2} \mathrm{O} \rightarrow \mathrm{MnO}_{2(\mathrm{~s})}+2 \mathrm{SO}_{4}{ }^{2-}+4 \mathrm{H}^{+}$ & {$[66,76]$} \\
\hline \multirow{4}{*}{$\mathrm{Ni}$} & Evaporation crystallization of $\mathrm{NiSO}_{4} \cdot 6 \mathrm{H}_{2} \mathrm{O}$ & N/A & [72] \\
\hline & Precipitation of Ni-Co-Mn hydroxide & $\mathrm{Ni}^{2+}+2 \mathrm{OH}^{-} \rightarrow \mathrm{Ni}(\mathrm{OH})_{2(\mathrm{~s})}$ & [10] \\
\hline & Precipitation of NiS or Ni-Co-Mn sulfide & $\mathrm{Ni}^{2+}+\mathrm{S}^{2-} \rightarrow \mathrm{NiS}_{(\mathrm{s})}$ & [10] \\
\hline & Precipitation of $\mathrm{Ni}(\mathrm{dmgH})_{2}{ }^{2}$ & $\mathrm{Ni}^{2+}+2\left(\mathrm{dmgH}_{2}\right) \rightarrow \mathrm{Ni}(\mathrm{dmgH})_{2(\mathrm{~s})}+2 \mathrm{H}^{+}$ & {$[65,66]$} \\
\hline \multirow{5}{*}{ Co } & \multirow{5}{*}{$\begin{array}{l}\text { Evaporation crystallization of } \mathrm{CoSO}_{4} \cdot 7 \mathrm{H}_{2} \mathrm{O} \\
\text { Precipitation of } \mathrm{CoC}_{2} \mathrm{O}_{4} \\
\text { Precipitation of } \mathrm{Co}_{3}\left(\mathrm{PO}_{4}\right)_{2} \\
\text { Precipitation of } \mathrm{Co}(\mathrm{OH})_{2} \text { or Ni-Co-Mn } \\
\text { hydroxide } \\
\text { Precipitation of } \mathrm{CoS} \text { or Ni-Co-Mn sulfide }\end{array}$} & N/A & [72] \\
\hline & & $\mathrm{Co}^{2+}+\mathrm{C}_{2} \mathrm{O}_{4}{ }^{2-} \rightarrow \mathrm{CoC}_{2} \mathrm{O}_{4(\mathrm{~s})}$ & {$[65,80]$} \\
\hline & & $3 \mathrm{Co}^{2+}+2 \mathrm{PO}_{4}{ }^{2-} \rightarrow \mathrm{Co}_{3}\left(\mathrm{PO}_{4}\right)_{2(\mathrm{~s})}$ & {$[81]$} \\
\hline & & $\mathrm{Co}^{2+}+2 \mathrm{OH}^{-} \rightarrow \mathrm{Co}(\mathrm{OH})_{2(\mathrm{~s})}$ & {$[10,66]$} \\
\hline & & $\mathrm{Co}^{2+}+\mathrm{S}^{2-} \rightarrow \operatorname{CoS}_{(\mathrm{s})}$ & {$[10]$} \\
\hline \multirow{3}{*}{$\mathrm{Li}$} & \multirow{3}{*}{$\begin{array}{l}\text { Reaction crystallization of } \mathrm{LiCO}_{3} \\
\text { Evaporation crystallization of } \mathrm{LiCO}_{3} \text { from } \\
\mathrm{LiHCO} 3 \text { solution } \\
\text { Reaction crystallization of } \mathrm{Li}_{3} \mathrm{PO}_{4}\end{array}$} & $2 \mathrm{Li}^{+}+\mathrm{CO}_{3}{ }^{2-} \rightarrow \mathrm{Li}_{2} \mathrm{CO}_{3(\mathrm{~s})}$ & {$[6,65,66,82]$} \\
\hline & & N/A & {$[72,83]$} \\
\hline & & $3 \mathrm{Li}^{+}+\mathrm{PO}_{4}{ }^{3-} \rightarrow \mathrm{Li}_{3} \mathrm{PO}_{4(\mathrm{~s})}$ & [84] \\
\hline
\end{tabular}

Note: ${ }^{1}$ As there are many known hydrated oxides of Fe(III), for the sake of simplicity we represent all of them as $\mathrm{Fe}(\mathrm{OH})_{3}$ in the above table. The varying degrees of hydration take the form of hydroxide disproportionation to oxide and water. The first precipitated Fe(III) hydrated oxide is known to be ferrihydrite, which has a variable hydration degree of 4-9 associated waters. ${ }^{2} \mathrm{dmgH}_{2}$ (dimethylglyoxime) is a chemical compound described by the formula $\mathrm{CH}_{3} \mathrm{C}(\mathrm{NOH}) \mathrm{C}(\mathrm{NOH}) \mathrm{CH}_{3}$.

As seen in Table 6, Cu precipitation (cementation) by adding iron is commonly used to recover $\mathrm{Cu}$ from acidic leach solution. Conventional precipitation techniques are suitable for the removal of impurities such as $\mathrm{Fe}(\mathrm{III})$ and $\mathrm{Al}(\mathrm{III})$ from acidic leach solutions, but the resulting precipitates are not pure. If selective precipitation of $\mathrm{Ni}(\mathrm{II}), \mathrm{Co}(\mathrm{II}), \mathrm{Mn}(\mathrm{II})$ is performed, further purification or transformation is required to obtain the final metal salts (or metal compounds) from the Li-ion battery materials, whereas evaporative crystallization can be used to produce pure metal salts. Evaporative 
crystallization is usually employed to produce $\mathrm{Ni}$, Co and Mn sulfates after solvent extraction as this is the conventional and mature technique. The more novel precipitation and crystallization methods reviewed in this paper have as yet scarcely been reported in connection with recycling of Li-ion batteries.

\section{Conclusions}

The unit operations precipitation and crystallization have been widely employed in hydrometallurgy. The reported methods, classified based on the induction of supersaturation include: evaporative crystallization, eutectic freeze crystallization, antisolvent crystallization, conventional reaction crystallization or precipitation, and homogeneous reaction crystallization or precipitation. Their mechanisms, advantages and some existing applications have been discussed. The characteristics of the hydrometallurgical streams and target products should dictate the selection of precipitation or crystallization methods used. Evaporative crystallization is a mature technique for producing $\mathrm{Ni}$, $\mathrm{Co}, \mathrm{Mn}$ sulfate salts. Eutectic freeze crystallization and antisolvent crystallization are energy saving and safe alternatives, but few case studies have been reported. Conventional precipitation is a poor choice for producing pure products, while homogeneous precipitation can offer some improvement. In addition, since the production of the metal salts from spent Li-ion batteries has become increasingly important, application of precipitation and crystallization processes in hydrometallurgical recycling processes for Li-ion batteries have also been reviewed. To date, the application of more novel and potentially superior precipitation and crystallization techniques for the recycling of Li-ion battery materials is lacking, but this situation is expected to change in the future.

Author Contributions: Y.M. is responsible for the main share of the literature review and wrote the main part of the manuscript. K.F. and M.S. are responsible for the conceptual idea, assisted with the review and the manuscript text. X.X., J.M.G. and R.T.O. provided some critical inputs and helped shape the manuscript. All authors have read and agreed to the published version of the manuscript.

Funding: This review was carried out within the PERLI (Processes for Efficient Recycling of Lithium Ion Batteries) project with grant number 48228-1, funded by the Swedish Energy Agency.

Conflicts of Interest: The authors declare no conflict of interest.

\section{References}

1. Burkin, A.R. Chemical Hydrometallurgy—Theory and Principles, 1st ed.; Imperial College: London, UK, 2001.

2. Demopoulos, G.P. Aqueous precipitation and crystallization for the production of particulate solids with desired properties. Hydrometallurgy 2009, 96, 199-214. [CrossRef]

3. Free, M.L. Hydrometallurgy: Fundamentals and Applications; John Wiley \& Sons, Inc.: Hoboken, NJ, USA, 2013.

4. Kim, Y. Lithium Nickel cobalt manganese oxide synthesized using alkali chloride flux: Morphology and performance as a cathode material for lithium ion batteries. ACS Appl. Mater. Interfaces 2012, 4, 2329-2333. [CrossRef]

5. Chikkannanavar, S.B.; Bernardi, D.M.; Liu, L. A review of blended cathode materials for use in Li-ion batteries. J. Power Sources 2014, 248, 91-100. [CrossRef]

6. Peng, C.; Liu, F.; Wang, Z.; Wilson, B.P.; Lundström, M. Selective extraction of lithium (Li) and preparation of battery grade lithium carbonate $\left(\mathrm{Li}_{2} \mathrm{CO}_{3}\right)$ from spent $\mathrm{Li}$-ion batteries in nitrate system. J. Power Sources 2019, 415, 179-188. [CrossRef]

7. Hubicki, Z.; Hubicka, H. Studies on the extraction process of nickel(II) sulphate purification using Cyanex 272. Hydrometallurgy 1996, 40, 65-76. [CrossRef]

8. Gupta, C.K.; Mukherjee, T.K. Hydrometallurgy in Extraction Processes, Volume II; CRC Press: New York, NY, USA, 1990.

9. Wang, J.; Ng, S.H.; Wang, G.; Chen, J.; Zhao, L.; Chen, Y.; Liu, H. Synthesis and characterization of nanosize cobalt sulfide for rechargeable lithium batteries. J. Power Sources 2006, 159, 287-290. [CrossRef]

10. Wang, H.; Friedrich, B. Development of a highly efficient hydrometallurgical recycling process for automotive Li-Ion batteries. J. Sustain. Metall. 2015, 1, 168-178. [CrossRef]

11. Ma, Y.; Stopic, S.; Friedrich, B. Hydrometallurgical treatment of a eudialyte concentrate for preparation of rare earth carbonate. Johns. Matthey Techol. 2019, 63, 2-13. [CrossRef] 
12. Herbert, R.B. Properties of goethite and jarosite precipitated from acidic groundwater, Dalarna, Sweden. Clays Clay Miner. 1997, 45, 261-273. [CrossRef]

13. Gupta, A.; Singh, P.; Shivakumara, C. Synthesis of $\mathrm{BaSO}_{4}$ nanoparticles by precipitation method using sodium hexa metaphosphate as a stabilizer. Solid State Commun. 2010, 150, 386-388. [CrossRef]

14. Tokoro, C.; Suzuki, S.; Haraguchi, D.; Izawa, S. Silicate removal in aluminum hydroxide co-precipitation process. Materials 2014, 7, 1084-1096. [CrossRef] [PubMed]

15. Burukhin, A.; Brylev, O.; Hany, P.; Churagulov, B.R. Hydrothermal synthesis of $\mathrm{LiCoO}_{2}$ for lithium rechargeable batteries. Solid State Ion. 2002, 151, 259-263. [CrossRef]

16. Van der Ham, F.; Witkamp, G.J.; de Graauw, J.; van Rosmalen, G.M. Eutectic freeze crystallization simultaneous formation and separation of two solid phases. J. Cryst. Growth 1999, 198/199, 744-748. [CrossRef]

17. Korkmaz, K.; Alemrajabi, M.; Rasmuson, Å.C.; Forsberg, K.M. Separation of valuable elements from NiMH battery leach liquor via antisolvent precipitation. Sep. Purif. Technol. 2020, 234, 115812. [CrossRef]

18. Kaya, S.; Peters, E.M.; Forsberg, K.; Dittrich, C.; Stopic, S.; Friedrich, B. Scandium Recovery from an Ammonium Fluoride Strip Liquor by Anti-Solvent Crystallization. Metals 2018, 8, 767. [CrossRef]

19. Kuang, G.; Li, H.; Hu, S.; Jin, R.; Liu, S.; Guo, H. Recovery of aluminium and lithium from gypsum residue obtained in the process of lithium extraction from lepidolite. Hydrometallurgy 2015, 157, 214-218. [CrossRef]

20. Dirksen, J.A.; Ring, T.A. Fundamentals of crystallisation kinetic effects on particle size distribution and morphology. Chem. Eng. Sci. 1991, 46, 2389-2427. [CrossRef]

21. Monhemius, A.J. Precipitation diagrams for metal hydroxides, sulfates, arsenates and phosphates. Trans. Inst. Min. Metall. C 1977, 86, 202-206.

22. Dean, J. Langes's Handbook of Chemistry, 13th ed.; McGraw-Hill, Inc.: New York, NY, USA, 1985.

23. Kristjánsson, I. Commercial production of salt from geothermal brine at reykjanes, Iceland. Geothermics 1992, 21, 765-771. [CrossRef]

24. Jiao, W.T.; Jiao, W.X. Purifying Industrial High Salt Waste-Water Involves Freezing and Recycling Sodium Sulfate Waste-Water, Discharging Brine into Freezer, Controlling Temperature, Cooling Precipitated Sodium Sulfate, and Evaporating Brine. Chinese Patent No. CN105110542A, 2 December 2015.

25. Wakisaka, M.; Shirai, Y.; Sakashita, S. Ice crystallization in a pilot-scale freeze wastewater treatment system. Chem. Eng. Process. Process. Intensif. 2001, 40, 201-208. [CrossRef]

26. Apsey, G.; Lewis, A.E. Selenium impurity in sodium sulphate decahydrate formed by eutectic freeze crystallization of industrial waste brine. J. South. Afr. Inst. Min. Metall. 2013, 113, 415-421.

27. Xu, H.; Zhang, Y.; You, H. Separation of potassium chromate by salting-out crystallization. Chin. J. Chem. Eng. 2007, 58, 930.

28. Gominšek, T.; Lubej, A.; Pohar, C. Continuous precipitation of calcium sulfate dihydrate from waste sulfuric acid and lime. J. Chem. Technol. Biotechnol. 2005, 80, 939-947. [CrossRef]

29. De Luna, M.D.G.; Bellotindos, L.M.; Asiaoa, R.N.; Lu, M. Removal and recovery of lead in a fluidized-bed reactor by crystallization process. Hydrometallurgy 2015, 155, 6-12. [CrossRef]

30. Monhemius, A.J.; Swash, P.M. Removing and stabilizing as from copper refining circuits by hydrothermal processing. JOM 1999, 51, 30-33. [CrossRef]

31. Ji, X.; Curcioa, E.; Obaidani, S.A.; Profioa, G.D.; Fontananovaa, E.; Drioli, E. Membrane distillationcrystallization of seawater reverse osmosis brines. Sep. Purif. Technol. 2010, 71, 76-82. [CrossRef]

32. Nitta, N.; Wu, F.; Lee, J.T.; Yushin, G. Li-ion battery materials: Present and future. Materialstoday 2015, 18, 152-264. [CrossRef]

33. Goriparti, S.; Miele, E.; Angelis, F.D.; Fabrizio, E.D.; Zaccaria, R.P.; Capiglia, C. Review on recent progress of nanostructured anode materials for Li-ion batteries. J. Power Sources 2014, 257, 421-443. [CrossRef]

34. Shobana, M.K. Metal oxide coated cathode materials for Li ion batteries-A review. J. Alloy. Compd. 2019, 802, 477-487. [CrossRef]

35. Bhatt, M.D.; O'Dwyer, C. Recent progress in theoretical and computational investigations of Li-ion battery materials and electrolytes. Phys. Chem. Chem. Phys. 2015, 17, 4799-4844. [CrossRef]

36. Balaji, S.; Mutharasu, D.; Subramanian, N.S.; Ramanathan, K. A review on microwave synthesis of electrode materials for lithium-ion batteries. Ionics 2009, 15, 765. [CrossRef]

37. Zhang, L.; Noguchi, H. Novel Layered Li-Cr-Ti-O Cathode Materials Related to the $\mathrm{LiCrO}_{2}-\mathrm{Li}_{2} \mathrm{TiO}_{3}$ Solid Solution. J. Electrochem. Soc. 2003, 150, A601-A607. [CrossRef] 
38. Kumari, T.S.D.; Jeyakumar, D.; Prem Kumar, T. Nano silicon carbide: A new lithium-insertion anode material on the horizon. RSC Adv. 2013, 3, 15028-15034. [CrossRef]

39. Bensalah, N.; Dawood, H. Review on Synthesis, Characterizations, and Electrochemical Properties of Cathode Materials for Lithium Ion Batteries. J. Mater. Sci. Eng. 2016, 5, 1000258.

40. Zhu, L.; Bao, C.; Xie, L.; Yang, X.; Cao, X. Review of synthesis and structural optimization of $\mathrm{LiNi}_{1 / 3} \mathrm{Co}_{1 / 3} \mathrm{Mn}_{1 / 3} \mathrm{O}_{2}$ cathode materials for lithium-ion batteries applications. J. Alloy. Compd. 2020, 841, 154864. [CrossRef]

41. Hu, G.; Du, K.; Peng, Z. Cathode Materials for Lithium Ion Batteries: Principle, Performance and Production of Technology; Chemical Industrial Press: Beijing, China, 2017. (In Chinese)

42. Li, W.; Lee, S.; Manthiram, A. High-nickel NMA: A cobalt-free alternative to NMC and NCA Cathodes for Lithium-Ion Batteries. Adv. Mater. 2020, 32, 2002718-2002724. [CrossRef] [PubMed]

43. Islama, M.; Yoona, M.; Parkb, Y.M.; Ura, S. Solid state synthesis of LiFePO4/C: Using low cost materials. J. Ceram. Process. Res. 2015, 16, 218-222.

44. Ter Horst, J.H.; Schmidt, C.; Ulrich, J. Fundamentals of Industrial Crystallization. Handb. Cryst. Growth 2015, 1317-1349. [CrossRef]

45. Wu, K.L.; Wang, H.Y.; Ward, J.D. Economic Comparison of Crystallization Technologies for Different Chemical Products. Ind. Eng. Chem. Res. 2018, 57, 12444-12457. [CrossRef]

46. Mellor, J.W. A Comprehensive Treatise on Inorganic and Theoretical Chemistry; Longmans, Green and Co.: London, UK, 1923; pp. 1922-1937.

47. Al-Mutaz, I.S.; Wazeer, I. Comparative performance evaluation of conventional multi-effect evaporation desalination processes. Appl. Therm. Eng. 2014, 73, 1194-1203. [CrossRef]

48. Zhou, Y.S.; Shi, C.; Dong, G. Analysis of a mechanical vapor recompression wastewater distillation system. Desalination 2014, 353, 91-97. [CrossRef]

49. Lu, H.; Wang, J.; Wang, T.; Wang, N.; Bao, Y.; Hao, H. Crystallization techniques in wastewater treatment: An overview of applications. Chemosphere 2017, 173, 474-484. [CrossRef] [PubMed]

50. Lu, X. Novel Applications of Eutectic Freeze Crystallization. Ph.D. Thesis, Technische Universiteit Delft, Delft, The Netherlands, 2014. ISBN 9789461863416.

51. Hubbe, M.A.; Becheleni, E.M.; Lewis, A.E.; Peters, E.M.; Gan, W.; Nong, G.; Mandal, S.; Shi, S.Q. Recovery of Inorganic Compounds from Spent Alkaline Pulping Liquor by Eutectic Freeze Crystallization and Supporting Unit Operations: A Review. BioResources 2018, 13, 9180-9219. [CrossRef]

52. Hasan, M.; Rotich, N.; John, M.; Louhi-Kultanen, M. Salt recovery from wastewater by air-cooled eutectic freeze crystallization. Chem. Eng. J. 2017, 326, 192-200. [CrossRef]

53. Randall, D.G.; Nathoo, J.; Lewis, A.E. A case study for treating a reverse osmosis brine using Eutectic Freeze Crystallization-Approaching a zero waste process. Desalination 2011, 266, 256-262. [CrossRef]

54. Fernández-Torres, M.J.; Randall, D.G.; Melamu, R.; von Blottnitz, H. A comparative life cycle assessment of eutectic freeze crystallisation and evaporative crystallisation for the treatment of saline wastewater. Desalination 2012, 306, 17-23. [CrossRef]

55. Van der Ham, F.; Witkamp, G.J.; de Graauw, J.; van Rosmalen, G.M. Eutectic freeze crystallization: Application to process streams and waste water purification. Chem. Eng. Process. 1998, 37, 207-213. [CrossRef]

56. Reardon, E.J. Ion interaction model applied to equilibria in the NiSO4-H2SO4-H2O system. J. Phys. Chem. 1989, 93, 4630-4636. [CrossRef]

57. Vaessen, R.J.C.; Janse, B.J.H.; Seckler, M.M.; Witkamp, G.J. Evaluation of the performance of a newly developed eutectic freeze crystallizer-Scraped cooled wall crystallizer. Chem. Eng. Res. Des. 2003, 81, 1363-1372. [CrossRef]

58. Weingaertner, D.A.; Lynn, S.; Hanson, D.N. Extractive crystallization of salts from concentrated aqueous solution. Ind. Eng. Chem. Res. 1991, 30, 490-501. [CrossRef]

59. Moldoveanu, G.A.; Demopoulos, G.P. Organic solvent-assisted crystallization of inorganic salts from acidic media. J. Chem. Technol. Biotechnol. 2015, 90, 686-692. [CrossRef]

60. Zhu, H.; Yuen, C.; Grant, D.J.W. Influence of water activity in organic solvent +water mixtures on the nature of the crystallizing drug phase. 1. Theophylline. Int. J. Pharm. 1996, 135, 151-160. [CrossRef]

61. Berry, D.A.; Dye, S.R.; Ng, K.M. Synthesis of drowning-out crystallization based separations. AIChE J. 1997, 43, 91-103. [CrossRef] 
62. Aktas, S.; Fray, D.J.; Burheim, O.; Fenstad, J.; Açma, E. Recovery of metallic values from spent Li ion secondary batteries. Miner. Process. Extr. Metall. 2006, 115, 95-100. [CrossRef]

63. Taboada, M.E.; Graber, T.A.; Cisternas, A.; Cheng, Y.S.; Ng, K.M. Process Design for Drowning-Out Crystallization of Lithium Hydroxide Monohydrate. Chem. Eng. Res. Des. 2007, 85, 1325-1330. [CrossRef]

64. Cohen, J.M. Applications of solvent displacement crystallisation in hydrometallurgy. In Separation Processes in Hydrometallurgy; GA D, Ed.; Ellis Horwood: London, UK, 1987.

65. Chen, X.; Chen, Y.; Zhou, T.; Liu, D.; Hu, H.; Fan, S. Hydrometallurgical recovery of metal values from sulfuric acid leaching liquor of spent lithium-ion. Waste Manag. 2015, 38, 349-356. [CrossRef]

66. Dhiman, S.; Gupta, B. Partition studies on cobalt and recycling of valuable metals from waste Li-ion batteries via solvent extraction and chemical precipitation. J. Clean. Prod. 2019, 225, 820-832. [CrossRef]

67. Åslund, B.L.; Rasmuson, Å.C. Semibatch reaction crystallization of benzoic acid. AIChE J. 1992, 38, 328-342. [CrossRef]

68. Wu, H.; Wang, Z.; Lin, W.; Wan, H. Preparation of Cobalt Hydroxide by Crystallization Control Method. Chin. J. Syn. Chem. 2018, 26, 619-623.

69. Huang, B.; Pan, Z.; Su, X.; An, L. Recycling of lithium-ion batteries: Recent advances and perspectives. J. Power Sources 2018, 399, 274-286. [CrossRef]

70. Lei, S.; Cao, Y.; Cao, X.; Sun, W.; Weng, Y.; Yang, Y. Separation of lithium and transition metals from leachate of spent lithium ion batteries by solvent extraction method with Versatic 10. Sep. Purif. Technol. 2020, 250, 117258.

71. Virolainen, S.; Fini, M.F.; Laitinen, A.; Sainio, T. Solvent extraction fractionation of Li-ion battery leachate containing Li, Ni, and Co. Sep. Purif. Technol. 2017, 179, 274-282. [CrossRef]

72. Hu, J.; Zhang, J.; Li, H.; Chen, Y.; Wang, C. A promising approach for the recovery of high value-added metals from spent lithium-ion batteries. J. Power Sources 2017, 351, 192-199. [CrossRef]

73. Tedjar, F.; Foudraz, J.-C. Method for the Mixed Recycling of Lithium-Based Anode Batteries and Cells. U.S. Patent No. 20070196725A1, 23 August 2007.

74. Lain, M.J. Recycling of Lithium Ion Cells and Batteries. J. Power Sources 2001, 97-98, 736-738. [CrossRef]

75. Kieran, D. Li-Ion Battery Recycling in the UK. In Proceedings of the 9th International Congress for Battery Recycling, Coma, Italy, 2-4 June 2004.

76. Zhang, X.; Li, L.; Fan, E.; Xue, Q.; Bian, Y.; Wu, F.; Chen, R. Towards sustainable and systematic recycling of spent rechargeable batteries. Chem. Soc. Rev. 2018, 47, 7239-7302. [CrossRef]

77. Sa, Q.; Gratz, E.; He, M.; Lu, W.; Apelian, D.; Wang, Y. Synthesis of high performance $\mathrm{LiNi}_{1 / 3} \mathrm{Mn}_{1 / 3} \mathrm{Co}_{1 / 3} \mathrm{O}_{2}$ from lithium ion battery recovery stream. J. Power Sources 2015, 282, 140-145. [CrossRef]

78. Schiavi, P.G.; Farina, L.; Zanoni, R.; Altimari, P.; Cojocariu, I.; Rubino, A.; Navarra, M.A.; Panero, S.; Pagnanelli, F. Electrochemical synthesis of nanowire anodes from spent lithium ion batteries. Electrochim. Acta 2019, 319, 481-489. [CrossRef]

79. Schiavi, P.G.; Altimari, P.; Zanoni, R.; Pagnanelli, F. Full recycling of spent lithium ion batteries with production of core-shell nanowires//exfoliated graphite asymmetric supercapacitor. J. Energy Chem. 2020, in press.

80. Chen, L.; Tang, X.; Zhang, Y.; Li, L.; Zeng, Z.; Zhang, Y. Process for the recovery of cobalt oxalate from spent lithium-ion batteries. Hydrometallurgy 2011, 108, 80-86. [CrossRef]

81. Chen, X.; Ma, H.; Luo, C.; Zhou, T. Recovery of valuable metals from waste cathode materials of spent lithium-ion batteries using mild phosphoric acid. J. Hazard. Mater. 2017, 326, 77-86. [CrossRef]

82. Chen, D.; Rao, S.; Wang, D.; Cao, H.; Xie, W.; Liu, Z. Synergistic leaching of valuable metals from spent Li-ion batteries using sulfuric acid- L-ascorbic acid system. Chem. Eng. J. 2020, 388, 124321. [CrossRef]

83. Zhang, J.; Hu, J.; Zhang, W.; Chen, Y.; Wang, C. Efficient and economical recovery of lithium, cobalt, nickel, manganese from cathode scrap of spent lithium-ion batteries. J. Clean. Prod. 2018, 204, 437-446. [CrossRef]

84. Huang, Y.; Han, G.; Liu, J.; Chai, W.; Wang, W.; Yang, S.; Su, S. A stepwise recovery of metals from hybrid cathodes of spent Li-ion batteries with leaching-flotation-precipitation process. J. Power Sources 2016, 325, 555-564. [CrossRef]

Publisher's Note: MDPI stays neutral with regard to jurisdictional claims in published maps and institutional affiliations. 